\title{
Propertius 1.3: Sleep, Surprise and Catullus 64
}

\section{Abstract}

Although previous scholarship has noted some verbal and stylistic allusions to Catullus in Propertius 1.3, the extent to which the poem offers a profound and detailed engagement with Catullus 64 has not been recognised. Through a close reading of the opening couplets, I hope to demonstrate the care, artistry and sophistication with which Propertius engages with Catullus 64, as he imitates and illuminates many of its key stylistic and intertextual features. I argue that this engagement with Catullus 64 is importantly programmatic, and that Propertius 1.3, like Catullus 64, is very much concerned with narrative authority and poetic control. This concern comes to the fore in Cynthia's speech at the close of the poem, and I hope to show through further close reading how its relationship to literature and art encourages us to question Propertius's portrayal of his relationship with Cynthia at this very early stage in the corpus.

Word Count: 15,415 
Propertius 1.3: Sleep, Surprise and Catullus 64

\section{'Just like the Cnosian woman...'}

Propertius 1.3 opens with an intriguing mix of mystery and mythology. The reader is presented with an arresting slideshow of three sleeping figures: first Ariadne, then Andromeda, and then a bacchant. Each figure is pictured against a different backdrop, ${ }^{1}$ and at least two of the sleepers evoke strong visual memories thanks to their long history in art. $^{2}$ All three are introduced as a comparison, but it is not immediately clear to whom or to what they are being compared. Indeed, it takes a while for the poem's dramatic context to come into focus: ${ }^{3}$ it is only in the fourth couplet that we discover that these mythological figures are suggested by the sight of the sleeping Cynthia, and only in the fifth that this is not some early morning reverie of the poet as he awakes next to his beloved, but rather the drunken fantasy of an inebriated Propertius, who comes shambling into her room late at night. ${ }^{4}$ As he approaches the couch, Propertius briefly contemplates taking full erotic advantage of the situation, acting out the kind of assault on a sleeping woman familiar from mythology, both in art and literature; ${ }^{5}$ but the thought quickly passes, and in place of

\footnotetext{
${ }^{1}$ Ariadne is on the shore (1.3.2 desertis ... litoribus); the bacchant is on the river bank, or perhaps in the dried-up river bed (1.3.6 in herboso ... Apidano: see e.g. R. J. Baker, Propertius 1. With an Introduction, Translation, and Commentary (Warminster 2000), and R. Hodge and R. Buttimore, The 'Monobiblos' of Propertius (Cambridge and Ipswich 1977) on this passage; that the location is specified for Ariadne and the Bacchant makes it more likely that the ablative in the phrase duris cotibus of 1.3.4 is one of place, locating Andromeda on the 'hard rocks': on this, see below and next note. ${ }^{2}$ The figures of the sleeping Ariadne and the sleeping Bacchant were frequently depicted in Greek and Roman art: see S. McNally, 'Ariadne and Others: Images of Sleep in Greek and Early Roman Art', ClAnt, 4 (1985) 152-92; E. Stafford, 'Aspects of Sleep in Hellenistic Sculpture’, BICS 38 (1993) 10520; G. Hedreen, 'Silens, Nymphs and Maenads', JHS 114 (1994), 47-69; R. Osborne, 'Desiring women on Athenian pottery’, in Sexuality in Ancient Art, ed. N. Kampen (Cambridge 1996) 65-80; J. Hodske, Mythologische Bildthemen in den Häusern Pompejis: die Bedeutung der zentralen Mythenbilder für die Bewohner Pompejis (Ruhpolding 2007), 154-63 and tables 21-35 (Ariadne). Although Andromeda also appears frequently in art, there is no trace of any representations of her asleep: see K. Phillips, 'Perseus and Andromeda', AJA 72 (1968) 1-23; Hodske, Bildthemen 180-83 and tables 63-7; and see further below. She is, however, often depicted bound on the mountain side, so if nothing else the landscape at least (duris cotibus) is certainly familiar from art.

${ }^{3}$ On this initial lack of context, and its relationship to the surrounding poems, see L. Curran, 'Vision and Reality in Propertius 1.3', YClS 19 (1966) 189-203 (190-94).

${ }^{4}$ The precise location of the room - whether it is in the house of Propertius or Cynthia — is not made clear. The komastic elements of the poem (on which see F. Cairns, 'Two Unidentified Komoi of Propertius: 1.3 and 2.29', Emerita 45 [1977] 325-53), and the fact that Cynthia's wool is at hand, may suggest that the scene is set at Cynthia's house (cf. Baker, Propertius [n. 1, above], on 1.3.11: and compare 2.29b); but as Lyne notes (O. Lyne, 'Propertius and Cynthia: Elegy 1.3', PCPhS 16 [1970] 60-78 [62]) there is a strong suggestion of domesticity here, of a husband returning late to his wife in their common home.

${ }^{5}$ In art we think primarily of the lusty satyrs approaching the sleeping bacchant, familiar primarily from Greek vase painting (for examples, see McNally, 'Ariadne' [n. 2, above]; Hedreen, 'Silens' [n. 2, above]; and Osborne, 'Women' [n. 2, above]), but attested elsewhere. In literature the closest analogues are to be found in the various (attempted) rape narratives in Ovid's Fasti, with Priapus (1.391-440, 6.319-48) and Faunus (2.303-58) approaching various sleeping females; and also in the oft-noted epigram of Paulus Silentarius (AP 5.275): of course, both texts are later than Propertius, but they may be looking back to earlier works of comedy or epigram. On the comic elements that may lie behind this poem, see G. Tatham, ““Just as Ariadne Lay ...”: Images of Sleep in Propertius 1.3', Scholia 9 (2000) 43-53. We may also think of Amymone (approached by a satyr and Poseidon: for more details see Tatham, 47). S. Harrison, 'Drink, suspicion and comedy in Propertius 1.3', PCPhS 40 (1994) 18-26, notes the danger that women may find themselves in when next to a river, comparing Tyro and
} 
lust we find a quick succession of emotions and images: a sudden anxiety at the recollection of his mistress' temper (17f.); ${ }^{6}$ an intense fascination as he (merely) gazes upon her, like that of Argos gazing at Io (19f.); ${ }^{7}$ a childlike joy at arranging Cynthia's hair (21-3); a naïve disappointment as his love-gift of apples tumbles to the floor (246); and an open-mouthed fear that every one of Cynthia's sighs betokens the unwelcome advances of a dream lover (27-30). The moon, peeping through the shutters, interrupts proceedings by waking Cynthia. No sooner does she wake than she begins to upbraid Propertius, suggesting that he has spent the night with another woman; the tone then changes to one of self-pity, as she recollects her vain attempts to stay awake, until ultimately succumbing to winged Sleep. Cynthia thus closes the poem with the very image with which it opened. ${ }^{8}$

The poem and its literary and artistic textures have been much discussed, ${ }^{9}$ in particular its relationship with Catullus 64. However, the extent of its engagement with Catullus 64 has not been fully recognised: indeed, I will argue that Propertius 1.3 can be read almost as a commentary on key stylistic and intertextual features of Catullus's epyllion. In what follows I hope first to establish the richness and importance of this engagement (particularly in the opening lines of 1.3), and then to explore the significance of this evocation of Catullus 64 for our reading of Propertius 1.3 - in particular those aspects of the Catullus poem which appear to present us with a problematic clash of opposing perspectives. This will require some detailed analysis of Catullus 64 as well as Propertius 1.3.

So let us turn now to the opening couplet, which in many ways showcases Propertius's relationship with Catullus 64 in this poem.

Poseidon (cf. e.g. Od. 11.235-59), Perimede and Achelous (Apollod. 1.7.3), and Ilia and Mars (cf. Ov. Fast. 3.11-24).

${ }^{6}$ When Propertius writes non tamen ausus eram dominae turbare quietem ('but I did not dare disturb the sleep of my mistress') the use of the term domina at the very moment when Propertius constrains his impulses in fear of Cynthia's rage nicely articulates the movement from an active (and potentially aggressive) role to a more passive one, and to the traditional subservience of the elegiac lover. But it should be noted, of course, that refraining from assaulting one's sleeping mistress is hardly a case of seruitium amoris. For other views on this couplet as a key turning point in the poem, see Curran, 'Vision' (n. 3, above), 200; R. Baker, 'Beauty and the Beast in Propertius 1.3', in Studies in Latin Literature and Roman History, ed. C. Deroux (Brussels 1980) 245-58 (251-3).

${ }^{7}$ This detail once again evokes a scene commonly depicted in art, and the progression in visual images nicely maps on to the change in P's attitude: in ll. 5-6 we see Propertius as a satyr creeping up on the sleeping Maenad; in ll. 13-14 we see Propertius being led towards a sleeping figure by Cupid (again common in art: see Hodske, Bildthemen [n. 2, above], tables 30-32). Here, however, he takes a more passive role, as Argos looking at Io.

${ }^{8}$ For more details on this, see below.

${ }^{9}$ Notable discussions include Curran, 'Vision' (n. 3, above); A. Wlosok, 'Die Dritte Cynthia-Elegie des Properz (Prop. 1, 3)’, Hermes 95 (1967) 330-52; Lyne, 'Propertius’ (n. 4, above) and The Latin Love Poets (Oxford 1980) 98-100 and 114-20; D. Harmon, 'Myth and Fantasy in Propertius 1.3', TAPhA 104 (1974) 151-65; F. Dunn, 'The Lover reflected in the Exemplum: A Study of Propertius 1.3 and 2.6’, ICS 10 (1985) 233-59; J. Noonan, 'Propertius I.3.3-4: Andromeda Is Missing', CJ 86 (1991) 330-36; Harrison, ‘Drink’ (n. 5, above); J. Zetzel, 'Poetic Baldness and Its Cure', MD 36 (1996) 73100; S. Kaufhold, ‘Propertius 1.3: Cynthia Rescripted’, ICS 22 (1997) 87-98; Tatham, ‘Ariadne’ (n. 5, above); J. Booth, 'Moonshine: Intertextual Illumination in Propertius 1.3.31-3 and Philodemus, Anth. Pal. 5.123', CQ 51 (2001) 537-44; B. Breed, 'Portrait of a Lady: Propertius 1.3 and Ekphrasis', CJ 99 (2003) 35-56; H. Valladares, 'The lover as a model viewer: gendered dynamics in Propertius 1.3', in Gendered Dynamics in Latin Love Poetry, ed. R. Ancona and E. Greene (Baltimore 2005) 206-42; J. Elsner, 'Viewing Ariadne: From Ekphrasis to Wall Painting in the Roman World', CP 102 (2007) 2044; C. Michalopoulos, 'Feminine speech in Roman love elegy: Prop. 1.3', LICS 10 (2011) 1-14. 
Qualis Thesea iacuit cedente carina languida desertis Cnosia litoribus...

Like the maid of Cnossus, as she lay languid on deserted shores when Theseus' ship departed... ${ }^{10}$

Propertius 1.3.1-2

Scholars have noted that this couplet recalls four lines of Catullus 64: with line 1 we can compare Catullus 64.53 Thesea cedentem celeri cum classe tuetur and 249 quae tum prospectans cedentem maesta carinam; and with line 2 we can compare Catullus 64.133 perfide, deserto liquisti in litore, Theseu and 172 Cnosia Cecropiae tetigissent litora puppes. However, previous scholarship has done little more than merely noting these echoes, ${ }^{11}$ and little attention has been paid to the complexity and sophistication of the intertextual games on display here.

That the phrase Thesea ... cedente carina picks up on Catullus 64.53 Thesea cedentem and 64.249 cedentem ... carinam is clear enough, but it should be noted that these are two particularly significant lines from Catullus 64, forming the beginning and the end of the Ariadne ekphrasis. Here it will be useful to put these lines in their context, as we will be returning to the surrounding verses a number of times. Here is the moment when the ekphrasis begins:

haec uestis priscis hominum uariata figuris 50

heroum mira uirtutes indicat arte.

namque fluentisono prospectans litore Diae,

Thesea cedentem celeri cum classe tuetur indomitos in corde gerens Ariadna furores, necdum etiam sese quae visit visere credit, utpote fallaci quae tum primum excita somno desertam in sola miseram se cernat harena. immemor at iuvenis fugiens pellit vada remis, irrita ventosae linquens promissa procellae. quem procul ex alga maestis Minois ocellis, saxea ut effigies bacchantis, prospicit, eheu, prospicit et magnis curarum fluctuat undis...

\footnotetext{
10 The translations of Propertius are based on that of G. Goold, Propertius (Cambridge, MA 1990), with modifications.

${ }^{11}$ Cf. e.g. Curran, 'Vision' (n. 3, above) 207, n. 22, who notes echoes of 'the vocabulary and alliteration' of Cat. 64.53 and 249 in line 1, and echoes of 64.133 and 172 in line 2. P. Fedeli, Il primo libro delle Elegie (Florence 1980) on 1.3.1 comments on the echoes of 64.53 and 249, and remarks that Ariadne is asleep in Propertius while awake in Catullus; Zetzel, 'Baldness' (n. 9, above) 84 notes the echo of 249; Breed, 'Portrait' (n. 9, above) 38, n. 11, refers back to Curran. Wlosok, 'Cynthia-Elegie' (n. 9, above) 338-39 comes closest to noting the significant location of these lines, but points only to the beginning of Ariadne's speech and the close of the ekphrasis.
} 
This cloth, varied with the ancient forms of men, with amazing skill reveals the virtues of heroes. For looking out on the wave-sounding shore of Dia, she sees Theseus departing with his swift fleet, bearing untamed madness in her heart - Ariadna. Not yet can she believe that she sees what she sees, since now, now first wakened from treacherous sleep she sees herself, poor wretch, deserted on the lonely sand. But forgetful the young man flies and strikes the waters with his oars, leaving unfulfilled his pledges to the gusty storm; at whom, from afar, from the weedy beach, the daughter of Minos, like a rocky statue of a bacchant, looks, alas, with sad little eyes, she looks and seethes with great waves of cares... ${ }^{12}$

Catullus 64.50-62

and here is the moment when the Ariadne ekphrasis comes to an end:

... qualem Minoidi luctum

obtulerat mente immemori, talem ipse recepit

quae tum prospectans cedentem maesta carinam

multiplices animo uoluebat saucia curas.

at parte ex alia florens uolitabat Iacchus..

[Theseus] himself received such grief as by forgetfulness of heart he had caused to the daughter of Minos, who at that time, gazing in sadness at the departing ship, was revolving manifold cares in her wounded heart. But in another part of the tapestry youthful Iacchus flitted...

Catullus 64.247-51

Propertius has noted the ring composition which opens and closes the Ariadne ekphrasis, and which is a key stylistic feature of Catullus $64,{ }^{13}$ and draws attention to it by merging Catullus's Thesea cedentem from the beginning of the ekphrasis with the cedentem carinam at its close, to produce the single phrase Thesea ... cedente carina. However, Propertius has also metamorphosed the Catullan Thēsěă, a Greek (masculine) accusative, into the exotic (feminine) adjective Thēsēà: although graphically the same, the word has undergone a metrical and morphological transformation from a dactylic noun in the accusative to a spondaic adjective in the ablative. This process, whereby one marks an allusion by making a slight change to the model, is a familiar poetic conceit: ${ }^{14}$ but it has special point here, because here at the opening of the poem, Propertius is playing the same game that Catullus played at

\footnotetext{
${ }^{12}$ Translations from Catullus are usually from Cornish (revised by G.P. Goold), in Catullus, Tibullus, Pervigilium Veneris (Cambridge, MA 1988), with modifications (sometimes extensive ones).

${ }^{13}$ See e.g. D. Traill, 'Ring-Composition in Catullus 64', CJ 76 (1981) 232-41 and 'Ring Composition in Catullus 63, 64 and 68b', CW 81 (1988) 365-69.

${ }^{14}$ Often with prefixes and suffices: cf. J. Zetzel, 'Catullus, Ennius, and the Poetics of Allusion', ICS 8 (1983), 251-66 (265); G. Giangrande, “'Arte Allusiva’ and Alexandrian Epic Poetry’, CQ 17 (1967) 85-97 (85).
} 
the opening of his poem; and Catullus was himself playing the same game as was played by one of his models, at the opening of his poem.

To make this clear, we will need to spend a little time on the first lines of Catullus 64.

\section{Peliaco quondam prognatae vertice pinus dicuntur liquidas Neptuni nasse per undas Phasidos ad fluctus et fines Aeeteos...}

Pine-trees of old, born on the top of Pelion, are said to have swum through the clear waters of Neptune to the waves of Phasis and the realms of Aeetes...

Catullus 64.1-3

It has long been recognised that these opening lines echo the opening of the Medea of both Euripides: ${ }^{15}$

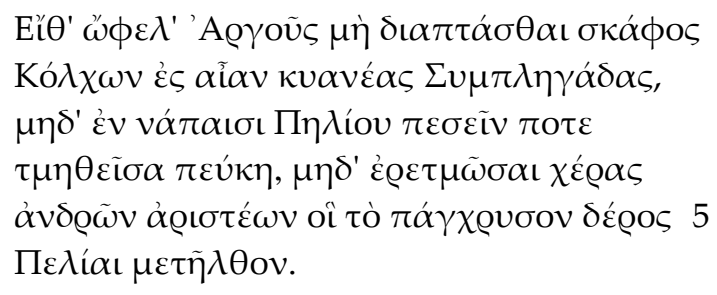

"Would that the Argo had never winged its way to the land of Colchis through the dark-blue Symplegades! Would that the pine trees had never been felled in the glens of Mount Pelion and furnished oars for the hands of the heroes who at Pelias' command set forth in quest of the Golden Fleece!”16

Euripides, Medea 1-6

and Ennius:

utinam ne in nemore Pelio securibus caesa accidisset abiegna ad terram trabes, neue inde nauis inchoandi exordium cepisset, quae nunc nominatur nomine Argo, quia Argiui in ea delecti uiri uecti petebant pellem inauratam arietis Colchis, imperio regis Peliae, per dolum.

\footnotetext{
${ }^{15}$ It should be noted that Catullus does not offer anything at the opening of his poem corresponding to the 'would that ... not' of Euripides and Ennius. However, we will find a correspondence a little later in the poem, discussed below.

${ }^{16}$ Translation from D. Kovacs, Euripides: Cyclops, Alcestis, Medea (Cambridge, MA 1994).
} 
Would that in the Pelian grove the firwood timber had not fallen to earth, hewn by axes; and that thereupon no prelude had been made to begin the ship which is now known by the name of Argo, because chosen Argive heroes were carried in it when they were seeking the golden fleece of the ram of Colchis, by trickery, at the behest of King Pelias. ${ }^{17}$

Ennius, Medea 208-14 Jocelyn

Richard Thomas has shown how the opening of Catullus 64 conflates these and other sources, in a complex intertextual game of multiple reference. ${ }^{18}$ He notes how in the first line of the poem Catullus preserves Ennius's 'correction' of Euripides' husteron-proteron: ${ }^{19}$ in Euripides, the nurse begins with the arrival of the Argo in Colchis, and then thinks of the felling of the trees on Mount Pelion to build the ship; in Ennius (and Catullus), the chronological order of these events is restored, and the felling of the trees on Mount Pelion is moved to first place. For Thomas, Catullus's new adjective Peliaco elevates the geographical reference to Mount Pelion and acts as a nod towards Ennius's reorganisation of these two events. ${ }^{20}$ However, more can be said here. I would argue that when Ennius 'corrects' Euripides by promoting Mount Pelion to his first line, he flags his 'correction' with an intertextual

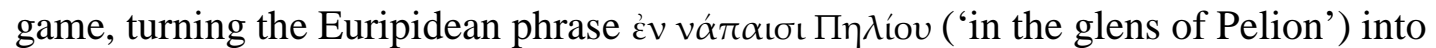
in nemore Pelio. Ennius echoes the sound of Euripides' Peliou in his Pelio, but has transformed what was a genitive of the noun 'Pelion' into the ablative form of an unusual adjective. Turning back to Catullus, I would argue that when he writes Peliaco it is more than just an 'elevation of [Ennius's] geographical reference': it is both a commentary on and a continuation of what Ennius has done with Euripides. The Pelio of Ennius becomes the Peliaco of Catullus, which presents us not only with another exotic adjectival form, previously unattested, but also - and importantly with a significant metrical transformation. As a result, the first word of Catullus 64, with its change from the tragic cretics of Pélĭou and Pélǐo into the dactylic form Pélǐăcō, announces (or appears to announce) a similar theme to Ennius and Euripides, but simultaneously heralds a change in generic identity.

So to return to Propertius, we can see how in the first line of his poem he has followed the lead of both Catullus - and Catullus's model Ennius — in the first lines

\footnotetext{
17 Translation from E. Warmington, Remains of Old Latin: Ennius and Caecilius (Cambridge, MA 1935).

${ }^{18}$ In R. Thomas, 'Catullus and the Polemics of Poetic Reference (Poem 64.1-18)', AJPh 103 (1982) 144-64. For further examples of the nature of Catullan intertextual play (primarily concerned with Apollonius), see R. Clare, 'Catullus 64 and the Argonautica of Apollonius of Rhodes: Allusion and Exemplarity’, PCPS 42 (1996) 60-88; and J. DeBrohun, 'Catullan Intertextuality : Apollonius and the Allusive Plot of Catullus 64’, in A Companion to Catullus, ed. M. Skinner (Malden, MA and Oxford 2007) 293-313.

19 Thomas, 'Catullus' (n. 18, above), 154-55.

${ }^{20}$ Thomas, 'Catullus' (n. 18, above), 155 writes of the first line 'Catullus has artfully indicated two of his primary sources by conflating them into a single line while yet preserving recognizable traces of the two originals'. This is precisely what Propertius has done in his opening line with the two lines of Catullus.
} 
of their poem: his transformation of Thēse $\breve{a}$ to Thessēa combines both the Ennian transformation of noun to adjective, and the Catullan change in metre.

Moving now to the second line (languida desertis Cnosia litoribus), we can see the same processes at work, as once again Propertius references significant lines and stylistic features from Catullus 64. Curran saw in this line echoes of two lines from Catullus 64: 133 perfide, deserto liquisti in litore, Theseu and 172 Cnosia Cecropiae tetigissent litora puppes: but once again there is more to be said here.

With desertis litoribus, we do indeed find an echo of the deserto ... in litore of 64.133, but once again it should be noted that this line forms a significant moment in the poem, namely the beginning of Ariadne's speech (64.132f. sicine me patriis avectam, perfide, ab aris, / perfide, deserto liquisti in litore, Theseu?). ${ }^{21}$ Furthermore, the phrase picks up on two recurring motifs from the Ariadne story - her loneliness and her location — that often appear together or close together. ${ }^{22}$

As Curran noted, with Cnosia litoribus Propertius's second line also recalls Catullus 64.172 Cnosia Cecropiae tetigissent litora puppes. In Catullus, these litora ('shores') are preceded by a long section on Ariadne's loneliness (164-70), but on this occasion the litora refer not to the shores of Dia but to the shores of Cnossos. Let us stay with the Catullan passage for a moment, and look at the line in context:

\section{Iuppiter omnipotens, utinam ne tempore primo} Cnosia Cecropiae tetigissent litora puppes

Almighty Jupiter, would that at the beginning the Attic ships had never touched Cnosian shores...

Catullus 64.171f.

Once again the passage to which Propertius alludes is a significant one, and in alluding to it Propertius once again demonstrates his awareness of Catullus's literary games. As noted above, the opening of Catullus 64 echoes the opening of the Medea of Euripides and Ennius, but we do not find anything in Catullus's opening lines corresponding to the 'would that ... not' construction that both Euripides and Ennius employ. ${ }^{23}$ However, this passage provides us with our 'missing' line: we now discover that it has not been omitted, but rather delayed, and placed in the mouth of Ariadne in the middle of her speech. ${ }^{24}$ Once again Catullus has combined his two models, following the meaning of Euripides ('would that the Argo had never come to

\footnotetext{
21 'Thus then, having borne me afar from my father's home, thus hast thou left me, faithless, faithless Theseus, on the lonely shore...'.

${ }^{22}$ In addition to the passage just quoted, we also find them at the beginning of the Ariadne ekphrasis (64.52 prospectans litore ... 57 desertam ... miseram se cernat). We find reference to Ariadne's abandonment again as she is about to begin her curse at 187 omnis sunt deserta.

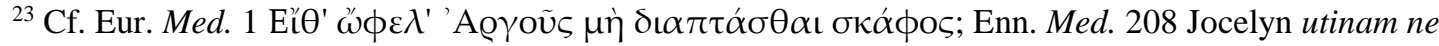
... accidisset ... trabes.

${ }^{24}$ I would suggest that in tempore primo we can see a glance towards the original position of this verse at the beginning of the Medeas of Euripides and Ennius.
} 
Colchis...') and the sound of Ennius: compare Ennius's utiname ne in nemore Pelio with Catullus's utinam ne tempore primo; or Ennius's caesa accidisset with Catullus's Cecropiae tetigissent.

Furthermore, Catullus has marked his allusion with a so-called 'golden line': that is to say, two adjectives, followed by a verb, followed by the two corresponding nouns in the same order as the adjectives (abVAB): Cnosia (a) Cecropiae (b) tetigissent (V) litora (A) puppes (B). This stylistic device is another feature of Catullus 64, which contains an unparalleled number of such lines. ${ }^{25}$

Once again, Propertius's poem acts almost as a commentary on Catullus: with languida desertis Cnosia litoribus he echoes the structure of the golden line, retaining the sequence of corresponding adjectives and nouns, but he marks the allusion with some changes. The verb is dropped, a symptom (and a reminder) of the change from hexameter to elegiac couplet; the 'shores' (litora) change both their metrical and geographical place: from first to second place in the series of nouns, and from the shores of Cnossos to the shores of Dia. Propertius also swaps the position, gender and function of Cnosia: as with Thesea, the graphical form remains the same, but what in Catullus was a neuter plural adjective (agreeing with litora) is in Propertius a feminine singular adjective serving as a noun, qualified by languida as an adjective.

In describing Ariadne as languida Propertius once again picks up on a key stylistic feature of Catullus 64, namely the way in which the same words and images re-appear throughout the poem in different contexts and with different meanings. ${ }^{26}$ This is true of languidus and its cognates in Catullus 64, where the words often appear in the contexts of vision and sleep, both pointedly appropriate to Propertius 1.3: Ariadne's eyes 'grow languid' in death (64.188 languescent lumina); the ageing Aegeus has 'languid eyes' (64.219f. languida lumina) that have not yet gazed enough on Theseus; and the Fates promise 'dear little languid sleep' (64.331 languidulos somnos) to be enjoyed by Peleus and Thetis on their wedding night. ${ }^{27}$ Furthermore, that Propertius is evoking this stylistic feature of Catullus 64 with his use of the word languida is confirmed by the fact that he will employ the same stylistic feature himself with the same word: languidus will re-appear towards the end of the poem, where it is used by Cynthia to describe Propertius, this time in a (clearly) sexual sense. ${ }^{28}$

\footnotetext{
${ }^{25}$ See K. Mayer, 'The Golden Line: Ancient and Medieval Lists of Special Hexameters and Modern Scholarship', in Latin Grammar and Rhetoric: Classical Theory and Modern Practice, ed. C. Lanham (London and New York 2002), 139-79.

${ }^{26}$ On this aspect of the poem, see R. Sklenár̆, 'How to Dress (For) an Epyllion: The Fabrics of Catullus 64', Hermes 134 (2004) 385-97.

${ }^{27}$ There is also the 'languid heart' of the fearful Ariadne (64.99 languenti corde) as she feared for Theseus in Crete.

${ }^{28}$ Prop. 1.3.38. There is disagreement amongst scholars as to whether languida should have a sexual sense in line 2. Scholars such as Lyne (in 'Propertius' [n. 4, above]) argue that it should not, and that there is a pointed difference between the two uses; scholars such as Baker (R. J. Baker, 'Beauty and the Beast in Propertius 1.3', in Studies in Latin Literature and Roman History vol. II, ed. C. Deroux (Brussels 1980), 245-58) and Harrison (in 'Drink' [n. 5, above]) argue that although the primary sense in line 2 is one of sleep, our awareness of the sexual sense helps to suggest Propertius' fears concerning Cynthia's own fidelity. Similar arguments apply to accubuit in the following couplet.
} 
Before we leave the first couplet, let us look a little more closely at Propertius's iacuit. Now, at first glance the word seems fairly colourless, and the fact that Catullus does not use the verb iaceo in poem 64 might suggest that there is little to be said here. However, the detail, density and sophistication of the other intertextual games in this opening couplet might make us more receptive to the possibility of an echo of another key moment in Catullus's poem, namely the beginning of the second ekphrastic scene and the arrival of Ariadne's divine lover-tobe at 64.251. Catullus does not refer to him here as Bacchus, or as Dionysus, or as Liber: but rather we read at parte ex alia florens volitabat Iacchus: Propertius's iacuit provides a sonic echo of a striking and uncommon name for Bacchus employed at a significant moment in the poem. ${ }^{29}$

\section{Andromeda and the Edonian}

So the opening couplet of Propertius 1.3 is something of a tour-de-force of learned allusion, and clearly establishes the link between the two poems. It also invites us to read the following couplets in the light of Catullus 64, and this I believe can help shed light on the second simile of the poem, in which Cynthia is compared to a sleeping Andromeda. But let us leave Andromeda in peace for a moment, and turn our attentions briefly to the third couplet:

\section{nec minus assiduis Edonis fessa choreis qualis in herboso concidit Apidano:}

'no less like the Edonian, exhausted after incessant dances, when she collapses on the grassy bank of the Apidanus...'

The final sleeping figure is a nameless 'Edonian woman', who has fallen asleep by the river Apidanus, exhausted by her dancing. The combination of dance, Thrace and sleeping outdoors strongly suggest that this is a bacchant. ${ }^{30}$ We may wonder what a Thracian bacchant is doing by the river Apidanus in Thessaly. Rather than dismiss these geographical specifications as mere poetic colouring, I would argue that we should read this inconsistency as pointed: it draws attention to the specific reference to the Apidanus in the pentameter, inviting us to ponder its significance. Once again the text points us back to Catullus 64: the Apidanus places us in Thessaly, the location

\footnotetext{
${ }^{29}$ That leaves only qualis unaccounted for. While Catullus does introduce two similes with qualis, both of them rather unusual (at 64.89f. describing the fragrant bed of Ariadne, and at 64.269-75 describing the departure of the viewers of the coverlet), the strongest case for intertextuality comes with Propertius's three-fold repetition of the word: as Curran, 'Vision' (n. 3, above) 193 notes, the repetition qualis ... qualis ... qualis calls to mind the Hesiodic Catalogue of Women, also known as the Ehoiae (from the formula ฑ̆ oí $\eta$ or in Latin, uel qualis). The Catalogue of Women forms an interesting intertext with Catullus 64, in that the Hesiodic poem appears to have begun describing a time when gods mixed freely with mortals (particularly mortal women — something of an inversion of Catullus 64, where a divine female is marrying a mortal man), while the final book introduces a time when gods and mortals no longer interact: this is of course very much the pattern of Catullus 64 .

${ }^{30}$ Edonia was a part of Thrace.
} 
of the marriage of Peleus and Thetis; ${ }^{31}$ but whereas Catullus envisages dancing taking place by the river Peneus in the vale of Tempe (64.285-7 confestim Penios adest, viridantia Tempe [...] / [...] linquens [...] celebranda choreis), Propertius places his dancing by another river in Thessaly, the Apidanus, and underscores the allusion by using the same rather exotic Greek form choreis, in the same metrical position.

I have left Andromeda until last, as she has proved considerably more troubling for scholars than her two companions. It is not the simile itself that causes problems: indeed, if we were to read the opening similes of the poem simply as evocative images of sleep, then Andromeda would provide a very potent one: she has spent an emotionally and physically exhausting night chained to a rock, awaiting death at the jaws of a terrifying sea-monster, before being freed from her chains and from mortal peril by one of the great heroes of mythology. This ordeal imbues her sleep with a special poetic quality, and as such it coheres well with the surrounding images of the sleeping Ariadne and the sleeping Bacchant.

However, it is when we look beyond the text that Andromeda becomes a little more troublesome. The figures of Ariadne and the Bacchant famously evoke scenes from art, scenes that had been familiar from many years by the time of Propertius. ${ }^{32}$ However, we know of no artistic representation of a sleeping Andromeda: ${ }^{33}$ surviving artistic representations show Andromeda exposed to the monster with Perseus engaged in (or about to engage in) battle, or at the moment of her liberation (by Perseus) from the rock, or seated next to Perseus gazing at a reflection of the Medusa's head. ${ }^{34}$ Nor does this scene appear to have been suggested directly by a scene in literature, though it must be said that we have only a few fragments of literary treatments before Catullus (see below).

Furthermore, scholars have also argued that the familiar artistic representations of Ariadne and the Bacchant supply us not just with a sleeping female, representing Cynthia, but also a male figure who can serve as an analogue for Propertius: in the case of Ariadne, either a Bacchus about to rescue her, or a Theseus who has just abandoned her; in the case of the Bacchant, a satyr or similar figure creeping up on the sleeping figure with erotic intent. ${ }^{35}$ At the very least, in both cases art provides a strong role for the male viewer. Now we clearly we could supply a male viewer in the case of Andromeda — namely Perseus - but then we run up against the problem that the location of the Andromeda simile, both in terms of its geographical position and its place in the Andromeda story, is far from clear. With the phrase libera ... duris cotibus we could take duris cotibus as ablative of location ('free, on the hard

\footnotetext{
31 The specification that this is an Edonian bacchant also has point. It reminds us of the story of Lycourgos, king of the Edonians, who resisted the worship of Dionysus in a rather aggressive fashion. According to Homer (Il. 6.129-40), he drove the nurses of Dionysus from the Nyseian hill, while Dionysus sought solace with Thetis; his punishment was (appropriately enough for a poem so concerned with viewing) blindness.

${ }^{32}$ See note 2.

${ }^{33}$ Or rather, no artistic representation of a sleeping woman has been identified as Andromeda.

${ }^{34}$ For Andromeda in art see Phillips, ‘Andromeda' (n. 2, above); Hodske, Bildthemen (n. 2, above) 180-83 and tables 63-7.

${ }^{35}$ See Curran, 'Vision' (n. 3, above) 196-97. Literature also provides us with various lusty deities with designs upon sleeping maidens: see note 5.
} 
rocks') or as an ablative of separation ('freed from the hard rocks'). ${ }^{36}$ Further complications are provided by the uncertain meaning of accubuit, which often has connotations of sleeping with somebody. ${ }^{37}$ If we are to supply a male who is viewing Andromeda, is this Perseus returning to a freshly-liberated (and now sleeping) Andromeda, still on the rocky crag? Or is the setting in a bedroom at the palace, after their marriage? Of course, as we shall see, Perseus does famously gaze on Andromeda, when he first catches sight of her exposed on the rock, but this occurs before he has slain the monster and before she has been freed.

All this makes Andromeda something of an awkward fit for various scholarly theories. ${ }^{38}$ For Curran, the 'discovery' of Ariadne and the Bacchant by the male is straightforward, but in the case of Andromeda we have to imagine that Propertius 'boldly fuses the moment of Perseus' discovery of Andromeda with the consummation of their marriage'; 39 for Harrison, while the Ariadne and Bacchant similes suggest Propertius's latent fears about Cynthia's fidelity, the Andromeda simile functions differently: in this case 'the effect is not suspicion of faithlessness but a comic reflection on the figure of the poet', as Perseus 'has earned his gaze on Andromeda by great deeds in her defence; the poet, on the other hand, has done nothing but get drunk...'; ${ }^{40}$ even Cairns, who takes a very different approach to the similes, arguing that the first and third scenes are komastic in nature, has trouble with Andromeda: he concludes that Propertius was motivated by a Hellenistic desire for a series of three similes, and inserted the Andromeda simile in the middle 'to disguise its inadequacy'. ${ }^{41}$

Now it may be that there was once a famous representation of Andromeda asleep that has left no trace and could remove these difficulties, ${ }^{42}$ but I would argue that these difficulties are deliberate, and that Propertius himself draws attention to his novel focus on Andromeda's sleep. Dunn suggests that Propertius emphasizes his unusual treatment of Andromeda with the phrase primo somno, since this is the only explicit mention of sleep in the three similes. ${ }^{43}$ I would add that here primo has

\footnotetext{
${ }^{36}$ In favour for the latter: H. Butler \& E. Barber, The Elegies of Propertius (Oxford 1933), P. Enk, Sex. Propertii Elegiarum Liber I (Leiden 1946), Fedeli, Primo libro (n. 11, above), L. Richardson, Propertius. Elegies I-IV (Norman, Oklahoma 1977), Goold, Propertius (n. 10, above), Lyne, 'Propertius' (n. 4, above); in favour of the former: M. Rothstein, Propertius. Die Elegien (Berlin 1898), Hodge \& Buttimore, Propertius (n. 1, above), Baker, Propertius (n. 1, above).

${ }^{37}$ Cf. OLD s.v. accumbo, §3. Elsewhere this is the primary meaning of the verb in Propertius: cf. e.g. 2.3.30, 2.30b.36, 3.15 .12 etc.

38 Though some try to explain the difficulties: Lyne, 'Propertius’ (n. 4, above) 68 suggests that the 'discrepancies between Cynthia's and Andromeda's situation ... are intentional and significant on a subtle level' - his idea is that while Andromeda may have been freed from her worries, Propertius has caused worry for Cynthia, with the result that he was 'far from being her Perseus'. Harmon, 'Myth' (n. 9, above) sees a natural progression in the similes: from Ariadne who sleeps in deluded bliss as Theseus sails away, to Andromeda who is truly freed from her cares, and will remain with her lover Perseus. On his scheme, it is the maenad who is the 'apparent anomaly' (156). For Dunn, 'Lover' (n. 9, above) 243-47, the apparent oddity of the Andromeda simile emphasises the romantic and chivalrous aspect of the story, which will find a parallel in Propertius's behaviour in lines 21-33.

${ }^{39}$ Curran, 'Vision' (n. 3, above) 197.

${ }^{40}$ Harrison, 'Drink' (n. 5, above).

${ }^{41}$ Cairns, 'Komoi’ (n. 4, above) 352.

42 This is maintained by some scholars; and some suggest that Propertius has here inserted Andromeda into a familiar artistic scene. For useful surveys of the various possibilities, see Dunn, 'Lover’ (n. 9, above) 243, n. 54; and S. Heyworth, Cynthia. A companion to Propertius (Oxford 2007) 16.

${ }^{43}$ Dunn, 'Lover' (n. 9, above) 247.
} 
metaliterary significance: this is the indeed the 'first' sleep of Andromeda in terms of her literary / artistic history. Furthermore, in changing the details of a familiar myth, Propertius is once again emulating the technique of Catullus $64 .{ }^{44}$

The attention drawn to Andromeda's unusual sleep, and her presence here between Ariadne and the Bacchant, invites explanation. One scholar has suggested that such an explanation is to be found in Andromeda's literary past, namely in tragedy. Both Sophocles and Euripides wrote an Andromeda, as did a number of Latin tragedians, though none of these tragedies has survived in anything more than a handful of fragments. ${ }^{45}$ For Noonan it is the Andromeda of Euripides that provides the answer, in two fragments that concern the 'uncertainty of seeing' and he argues that this informs other kinds of uncertainty in Propertius 1.3. ${ }^{46}$ While I am not persuaded by Noonan's suggestions, ${ }^{47}$ I do believe that the Andromeda of Euripides does have an important role to play in understanding this couplet, but primarily through the intermediary of Catullus 64.

The Medea of Euripides and Apollonius is very much a presence in Catullus 64, as has been well documented, but I would suggest that Catullus also has an eye on the tragic figure of Andromeda: she is another famous abandoned woman with a literary history of lamentation, and she provides an interesting contrast to Medea and Ariadne: whereas the latter both abandon their parents to follow a stranger who then abandons them, Andromeda is first abandoned by her parents (who chain her to the rock to be devoured by the monster), before abandoning them in turn to follow Perseus. ${ }^{48}$ Unlike Medea and Ariadne, hers will prove to be a happy and fruitful marriage.

The fragmentary state of the Andromeda tragedies makes it hard to ascertain the full extent to which Catullus is engaging with her literary history, but we have enough to establish a relationship between Catullus 64 and the Andromeda of Euripides. One passage in particular contains a cluster of mutually-reinforcing intertexts with the tragedy:

si tibi non cordi fuerant conubia nostra, saeva quod horrebas prisci praecepta parentis, attamen in vestras potuisti ducere sedes, quae tibi iucundo famularer serva labore,

\footnotetext{
${ }^{44}$ On this see below.

${ }^{45}$ Assembled in R. Klimek-Winter, Andromedatragödien: Sophokles, Euripides, Livius Andronikos, Ennius Accius. Text, Einleitung und Kommentar (Stuttgart 1993).

${ }^{46}$ Noonan, 'Propertius’ (n. 9, above).

${ }^{47}$ Noonan is primarily concerned with 'uncertain or competing perceptions' (as I am), but he is thinking here in terms of P's concerns with 'uncertainty of seeing'. He believes that there is uncertainty in the situation of the three mythological women (Ariadne has been abandoned, but will curse Theseus and become the consort of Dionysus; the Edonian Bacchant suggests the mistreatment of the Edonian Bacchants by Lycurgus but also his punishment; Andromeda has been rescued, but there will be subsequent problems in her decision to stay with Perseus); he also argues that the uncertainty of vision is paralleled by an uncertainty of emotion — 'a wavering between pleasure and pain' — that is part of the dynamic of the relationship between Cynthia and Propertius.

${ }^{48}$ For discussion of the Andromeda myth, see F. Bubel, Euripides. Andromeda (Stuttgart 1993); Klimek-Winter, Andromedatragödien (n. 45, above), C. Collard et al., Euripides: Selected Fragmentary Plays Vol II (Warminster 2004).
} 
candida permulcens liquidis vestigia lymphis, purpureave tuum consternens veste cubile. sed quid ego ignaris nequiquam conqueror auris, exsternata malo, quae nullis sensibus auctae 165 nec missas audire queunt nec reddere voces? ille autem prope iam mediis versatur in undis, nec quisquam apparet vacua mortalis in alga. sic, nimis insultans extremo tempore saeva, fors etiam nostris invidit questibus aures.

If you had no mind to wed with me for dread of the harsh bidding of your stern father, yet you could have led me into your dwellings to serve you as a slave with labour of love, washing your white feet with liquid water, or with purple coverlet spreading your bed. But why should I, distracted with woe, cry in vain to the senseless airs - the airs that are endowed with no feeling, and can neither hear nor return the messages of my voice? He meanwhile is now tossing almost in mid-sea, and no human being is seen on the waste and weedy shore. Thus fortune too, full of spite, in this my supreme hour has cruely grudged all ears to my complaints...

Catullus 64.158-70

When Ariadne suggests to Jason that if he did not want her as a wife, then she could at

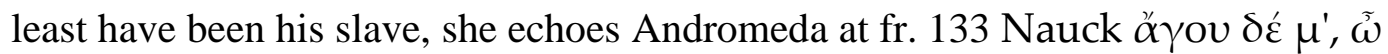

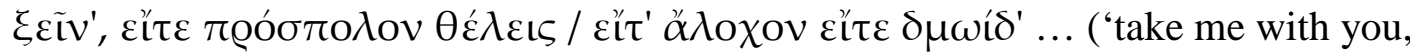
stranger, whether you want me as a servant, a wife or a slave...'). That Catullus has the Andromeda in mind is confirmed by the intertextual play that immediately follows. In Euripides’ play, Andromeda’s opening lament was famously interspersed with a response by Echo, whom Andromeda addresses at one point (fr. 118 Nauck): Catullus's Ariadne, however, marks her difference from Andromeda by explicitly denying the presence of any echo (64.164-6 auris ... quae ... nec missas audire queunt nec reddere voces), especially a personified one (aurae ... quae nullis sensibus auctae). ${ }^{49}$ Ariadne then continues, complaining that there is no one present to hear her complaint (fors etiam nostris invidit questibus aures): this in contrast to Andromeda who explicitly asks Echo to stop so that she might lament with her friends, and gain some solace as a result (frr. 118 and 119 Nauck). ${ }^{50}$

However, the most important allusion for our purposes is one that comes at a very significant moment in Catullus 64:

immemor at iuvenis fugiens pellit vada remis, irrita ventosae linquens promissa procellae. quem procul ex alga maestis Minois ocellis,

\footnotetext{
49 There may be a glance here to Aristophanes’ parody of Euripides’ Andromeda at Thesm. 1056-97, where Euripides-as-Echo appears as a character.

${ }^{50}$ We should also remember that Andromeda’s predicament was brought about by her mother boasting that her beauty surpassed that of the Nereids: the Nereids who, of course, feature at the beginning of Catullus 64.
} 
saxea ut effigies bacchantis, prospicit, eheu, prospicit et magnis curarum fluctuat undis...

But forgetful the young man flies and strikes the sea with his oars, leaving unfulfilled his promises to the gusty storm: at whom, from afar, from the weedy beach, the daughter of Minos, like a rocky statue of a bacchant, looks, alas, with sad little eyes, she looks and seethes with great waves of cares...

Catullus 64.58-62

With saxea ut effigies bacchantis Catullus introduces the very first simile of the poem, and as he does so, he presents us with a striking collision of different perspectives. First of all, we note that Ariadne, who is a figure in a tapestry and herself a work of art, is compared within the ekphrasis to another work of art, a 'statue of a bacchant'. The simile is a striking one, in as much as the statue suggests stillness while the bacchant suggests frenzied motion. ${ }^{51}$ Furthermore, Ariadne is compared to something to be viewed at the very moment that she herself is viewing (ut effigies [...] prospicit). This latter point is underlined by an echo of Euripides' Andromeda: the simile recalls the moment in the tragedy when Perseus arrives, flying through the air, and catches sight of Andromeda chained to a rock. At first he mistakes her for a statue:

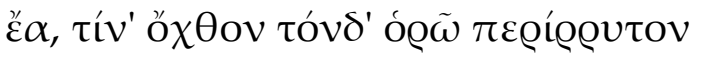

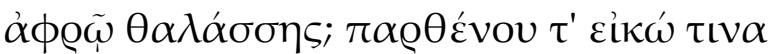

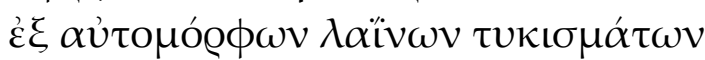

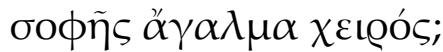

"But lo, what hill is this I see, with sea-foam flowing round? What image of a maiden perfectly carved in stone, the beautiful product of an artful hand?"52

Euripides, Andromeda fr. 124 Nauck

Catullus's striking adjective saxea flags the allusion, picking up the $\lambda \alpha{ }^{\prime \prime} v \omega v$ of Euripides, ${ }^{53}$ and as noted above, the allusion reinforces the change in perspective: like Andromeda, Ariadne is compared to a statue, but whereas Andromeda is viewed by Perseus as he arrives, Ariadne is the viewer, gazing after Theseus as he departs. This change in perspective is also gendered, with the result that Ariadne simultaneously plays both male and female roles: on the one hand, Ariadne gazes like the male Perseus, while at the same time she is gazed upon, twice over, as a woman depicted

\footnotetext{
${ }^{51}$ On this see W. Fitzgerald, Catullan Provocations: Lyric Poetry and the Drama of Position (Berkeley and London 1995), 154.

52 Translation from Collard et al., Euripides (n. 48, above).

${ }^{53}$ It also catches the irony inherent in Perseus mistaking Andromeda for a stone statue: Perseus is of course carrying the Gorgon's head, the effect of which is to turn anyone who sees it to stone. The Gorgon's head is a useful symbol for the dangers of gazing at something extraordinary...
} 
on a work of art both on the coverlet and in the simile. The net result is that the figure of Ariadne is now a locus for a very complex clash of perspectives, or to put it another way, a simultaneous combination of opposites: she is motionless but full of frenzy, she is Perseus but also Andromeda, a (male) viewer yet also the (female) object to be viewed. ${ }^{54}$

So in the first simile of his poem, Catullus compares Ariadne to a Bacchant, in terms which evoke Andromeda: these are of course the same trio of figures that we find at the beginning of Propertius 1.3. I would argue that their presence here provides further impetus to recall Catullus $64,{ }^{55}$ and to recall in particular a moment in that poem which once again orchestrates not just significant intertextual play, but also a significant clash of perspectives. As we shall see, this significant clash of perspectives — this simultaneous combination of opposites — is something that will be of considerable importance to Propertius as well.

\section{Propertius and Catullus}

At this point, let us pause to think more broadly about the relationship between these two poems. If we accept that Propertius 1.3 does engage closely with Catullus 64, the next question to consider is what an awareness of this engagement brings to our reading of Propertius 1.3.

The question has been considered by other scholars: for Curran, echoes of Catullus help to underline the importance of the Ariadne exemplum for the interpretation of the poem, and to articulate the shift in roles of Propertius from heroic Bacchus to a 'discredited Theseus'; ${ }^{56}$ for Zetzel, Propertius uses Catullus in 1.3 in a programmatic fashion, to define 'his love and love poetry in relation to Catullus's but also to establish a distance from him: ${ }^{57}$ Zetzel argues that in making explicit (and oversimplifying) Catullus's implicitly autobiographical use of myth to describe his relationship, Propertius suggests that such equations are unrealistic; Elsner reads Propertius 1.3 against Catullus 64 in terms of the gaze: the gaze is a key theme of Catullus 64, and gazing is a key activity of many of its characters; ${ }^{58}$ in Propertius 1.3 , however, the gaze belongs to the poet in the first-person, where it becomes 'the

\footnotetext{
${ }^{54}$ Her status as both viewer and viewed is nicely expressed at 64.57 with miseram se cernat 'she sees herself in a wretched state'.

${ }^{55}$ In addition to this more general allusion, Propertius once again picks up some details from Catullus 64: primo ... somno looks to and inverts the opening of the ekphrastic passage in Catullus 64.56 utpote fallaci quae tum primum excita somno: primum has become the adjective primo, now agreeing with somno, and the moment is changed from waking to sleep (and we will find similar play with this line at the end of Propertius 1.3). Both women are referred to as their father's daughter, but where Catullus uses the patronymic Minois, Propertius varies this with the adjectival Cepheia.

${ }^{56}$ Curran, 'Vision’ (n. 3, above), esp. 196-97 and 206-07.

57 Zetzel, 'Baldness' (n. 9 above). For Zetzel, the evocation of Catullus in 1.3 is to be seen in the context of series of programmatic allusions in the opening poems of Propertius's first book, in which Propertius 'reveals his awareness of his debt to the tradition (Gallus [in 1.1], probably Philetas [in 1.2], Catullus [in 1.3]), exaggerates the tendencies of his models, and while apparently rejecting them, continues to remain well within the lines that they had laid out' (90).

${ }^{58}$ Elsner, 'Ariadne' (n. 9, above). He argues that the gaze of all the characters within the ekphrasis is unfulfilled, in contrast to the fulfilled gaze of the Thessalian spectators: 'the challenge to the reader is whether the unfulfilled gazes inside the tapestry (all of various forms of mythic disaster) or the sated gaze at the coverlet are the more appropriate models for our response to the poem as a whole' (25).
} 
ambivalent, multifaceted, and confused authorial gaze of a lover who cannot be fulfilled'. Breed is concerned with the 'reality' of Cynthia's voice, and how it affects our reading of Cynthia more generally: ${ }^{59}$ he argues that the echoes of Catullus 64 and its deliberately problematic relationship with reality invite reflections on the nature of representation in Propertius: the mimetically problematic aspects of Ariadne's voice in the Catullan ekphrasis, together with the intertextual content of Cynthia's speech, reveal that rather than a contrast between visual fantasy at the start of 1.3 and harsh reality at the close, Propertius is presenting Cynthia to the reader through different types of representational fiction.

I would argue that this poem is importantly programmatic in a number of ways. First, on a general level, I believe that in 1.3 we can see an acknowledgement of Propertius's debt to Catullus. Propertius Book 1 contains little by way of explicit meta-poetic comment, but I find Zetzel's suggestion that the opening poems of the book help (implicitly) to situate and define Propertius's poetry in relation to earlier poets and poetic traditions attractive, even if I would disagree with him on the precise nature of that relationship. I would suggest that in his recognition and reproduction of the technique of Catullus 64, which forms the centrepiece and in some ways the showpiece of the Catullan corpus, the young poet is making a bold claim about his poetic models and his own poetic powers. ${ }^{60}$

However, I would also argue that Propertius 1.3 is also programmatic in a more specific sense, and one that influences the way we read Propertius as a whole. With Breed I would suggest that the problems that surface in Catullus 64 regarding representation are key to understanding this poem. However, I would argue that Catullus 64 raises problems of poetic composition that go beyond mimesis, and that reading Propertius 1.3 in the light of Catullus 64 makes us question not just Propertius's representation of Cynthia, but Propertian representation more generally.

My reading of Catullus 64 is that it is a poem very much concerned with truth and trustworthiness, and the control the poet exerts over his creation. Ariadne's exclamation that no man can be trusted (ll. 143f.) has a resonance that extends beyond her immediate situation to encompass many aspects of this dazzlingly peculiar text, a text which constantly undermines or complicates its own truth status, contradicting either what we think we know, or occasionally what it explicitly tells us. For example, the poet tells us that the Argo is the first ship, ${ }^{61}$ but then it turns out that it cannot be; ${ }^{62}$ he suggests that the bed-cover will contain the 'manly deeds of heroes', but instead all we see is Ariadne's desertion and discovery; well-known and familiar aspects of the various myths are explicitly contradicted, such as the relative chronology of the marriage and the voyage of the Argo, the (un)happiness of the marriage between Peleus and Thetis, or the absence of Apollo and the presence of the Fates at the wedding. ${ }^{63}$ This aspect of Catullus 64 has been particularly well investigated by

\footnotetext{
${ }^{59}$ Breed, 'Portrait' (n. 9 above).

${ }^{60}$ As Zetzel notes, and as we shall see below, 1.3 looks to other poems of Catullus besides 64 .

${ }^{61}$ Cf. 64.11 and 15.

${ }^{62}$ Because the story of Ariadne and Theseus involves sailing.

${ }^{63}$ For details see J. Gaisser, 'Threads in the Labyrinth: Competing Views and Voices in Catullus 64', AJPh 116 (1995) 579-616, and J. O’Hara, Inconsistency in Roman Epic (Cambridge 2006), 33-54.
} 
O’Hara and by Gaisser, ${ }^{64}$ and the latter nicely encapsulates something very important for Propertius 1.3 when she describes Catullus 64 as 'a work of competing perspectives whose authority is repeatedly called into question' (579). As Gaisser notes, in such a complex poem, we must remember that we are getting the story of Theseus's departure very much from Ariadne's perspective: as far as Ariadne is concerned, she has been abandoned by the forgetful (immemor) and perfidious Theseus; but Gaisser looks to the scholia to Theocritus for another side to the story, where Theseus's lapse of lapse of memory is said to be the work of Dionysus. But Catullus's evocation of artistic representations of Ariadne should remind us of yet another perspective, another complicating voice: namely the one in which Athena is responsible for Theseus's departure, leading him away from the sleeping Ariadne. ${ }^{65}$ Gaisser compares Catullus's poem to the Labyrinth, and the comparison is a good one: indeed, for Catullus, as for Daedalus, this labyrinthine creation showcases the artist's control over his materials, and his power over the reader.

Furthermore, these 'competing perspectives' (to use Gaisser's term), or these 'inconsistencies' (to use O'Hara's) complicate our response to the narrative. We can no longer simply believe what our narrator is telling us: as Clare puts it, the 'antagonism ... between Catullus' literary allusions and the narrative they are supposed to illuminate' reminds us that 'nothing remains as it seems at first sight. Interpretation is negotiable...'. ${ }^{66}$ For O'Hara too, the inconsistencies open up a credibility gap: 'Catullus' strong use of incompatible variants serves to undercut the authority of the speaking voice - not the poet behind the creation of the poem, but the voice of the speaker — and to call attention to the fictionality of the work' ${ }^{67}$

I would argue that it is precisely these aspects of poem 64 - the use of inconsistencies to draw attention to the fictionality of the work and to undermine the authority of the speaking voice - that Propertius's engagement with Catullus invites us to recall. It is for this reason that while I am broadly in agreement with Breed's arguments regarding the problem of 'representation' in 1.3 and Catullus 64, I would suggest this is only one aspect of a broader concern that both poems share, namely that of problematic narrative authority more generally.

As we have seen, in Catullus 64 these inconsistencies, or to put it another way, these 'combinations of opposites' are sometimes factual (e.g. the Argo is the first ship, but it is not), and sometimes more conceptual (Ariadne is a statue, Ariadne is bacchant). In the latter category we could add the latent play with gender (Ariadne is a male viewer, but also a female object of the gaze). This play with gender resonates strongly with the rest of the Catullan corpus, in which a confusion of gender roles becomes one of the hallmarks of Catullan passion: Catullus is a male poet, but an

\footnotetext{
${ }^{64}$ See also Thomas, ‘Catullus’ (n. 18, above); Zetzel, ‘Allusion’ (n. 14, above); and Clare, 'Argonautica' (n. 18, above).

${ }^{65}$ Cf. McNally, ‘Ariadne’ (n. 2, above) and cf. e.g. LIMC 3, addenda, s.v. Ariadne, nos. 52 and 54. To this extent, just as Ariadne's memini at Fasti 3.473 has a strong literary sense (and a nice contrast with immemor Theseus), so too there might be an irony here in Theseus' description as immemor: for all Ariadne's complaints about Theseus' forgetfulness, she (but not the reader) has forgotten a range of traditions that would excuse his behaviour.

${ }^{66}$ Clare, 'Argonautica' (n. 18, above) 81.

${ }^{67}$ O’Hara, Inconsistency (n. 63, above) 42-3.
} 
emasculated, effeminized lover; he is both Protesilaus and Laodamia. ${ }^{68}$ It is not surprising then that many have seen Ariadne both as abandoned heroine and as a mouthpiece for Catullus.

This play with gender becomes a key part of elegiac self-presentation, and I would suggest that in 1.3 it is this highly influential 'combination of opposites' in particular that Propertius employs both to signal the importance of Catullus for the elegiac tradition, but also to draw attention to the fictionality of his own narrative, and to the gap between poet and narrator.

\section{Both Male and Female...}

As we shall see, gender ambiguity will come to the fore in the final part of the poem, but the stage is being set throughout the earlier parts of 1.3. The text presents us with many cases of gender uncertainty, and underlines this uncertainty with echoes of various Catullan poems that engage in similar play with gender. ${ }^{69}$

In lines 7-8 Cynthia seems to 'breath soft quiet' (mollem spirare quietem): the phrase is both epic but feminine, recalling but refashioning Homer's 'breathing fury'. ${ }^{70}$ Moreover the combination mollis quies is surprisingly rare, occurring in extant Latin only once before, where it is used (appropriately enough) of the uncertainly-gendered Attis and his companions at Catullus 63.38 and 44; the context of the phrase shares further elements with 1.3, in that it is used first as they go to sleep, and then as Attis awakes.

It is against this background that we should read the uncertain reference of ebria in line 9. At first it seems as if ebria refers to Cynthia, and it is she who is drunk, but when we read further we discover that ebria in fact describes the feet of Propertius. ${ }^{71}$ So too with the uncertainty regarding the hands and bosom of lines 24$26:^{72}$ as we shall see, this confusion of whether we are dealing with Propertius or Cynthia anticipates the close of the poem to some extent, and it is not by accident that this uncertainty is underlined by another echo of Catullan gender-uncertainty: the apples that fall from the bosom of either Propertius or Cynthia at ll. 24-26 recall the apples that fall from the blushing virgin of Catullus 65.19-24, a blushing virgin who in this simile corresponds to Catullus. We should perhaps remember at this point that the figure of Bacchus, to whom Propertius is implicitly compared, was in some manifestations famously sexually ambiguous. ${ }^{73}$

\footnotetext{
${ }^{68}$ On this aspect of Catullus see M. Skinner, 'Ego Mulier: The Construction of Male Sexuality in Catullus', Helios 20 (1993) 107-30.

69 There are some other echoes of Catullus noted by Curran, 'Vision' (n. 3, above) and Zetzel, 'Baldness' (n. 9, above), though not all of them convince. For some general stylistic traits, see D. Ross, Backgrounds to Augustan Poetry: Gallus, Elegy and Rome (Cambridge 1975) 54-55, though he does not believe that there to be any precise echoes of Catullus 64. For a summary, see Breed, 'Portrait' (n. 9, above) 38-40.

${ }^{70}$ As noted by Lyne, 'Propertius' (n. 4, above) 68. For the phrase $\mu \varepsilon \dot{v \varepsilon \alpha ~ \pi v \varepsilon i ́ o v \tau \varepsilon \varsigma, ~ c f . ~ e . g . ~ H o m . ~ I l . ~}$ 2.536, 3.8, 11.508 .

${ }^{71}$ Cf. Harmon, 'Myth’ (n. 9, above) 157. Lyne, 'Propertius’ (n. 4, above) disagrees, arguing that not every uncertainty is deliberate.

${ }^{72}$ Harmon, 'Myth' (n. 9, above) 160, n. 30 also believes the confusion is deliberate.

${ }^{73}$ Cf. e.g. in Euripides’ Bacchae.
} 
But it is at the close of the poem that we will encounter the most significant gender ambiguity, and the most significant problems with the credibility of the poet's persona, when Cynthia finally rouses from her slumber.

\section{Cynthia awake}

A common reading of 1.3 contrasts the romantic 'ideal' picture of the sleeping Cynthia that opens the poem with the harsh 'reality' of the woken Cynthia that brings the poem to a close: she is a 'shrewish nag who destroys the lover's lofty visions of beauty and tenderness', ${ }^{74}$ she 'justifies all too well Propertius's fears of her saeuitia', ${ }^{75}$ she 'attacks him with the fury of an enraged Maenad' ${ }^{76}$ she delivers a 'harangue, ${ }^{77}$ in a 'savage outburst'. ${ }^{78}$ However, if we look closely at the speech, such extreme language seems hard to justify. ${ }^{79}$ The first three couplets may have an accusatory tone, but the final three modulate to a gentle tone of self-pity. ${ }^{80}$

If there is a mis-reading here, however, it is one that is encouraged by Propertius, who sets up the reader to expect a violent reaction from Cynthia: he reminds us of his fear of her harsh temper (the iurgia saeuitiae of 17-18); and in comparing the sleeping Cynthia to the sleeping figures Ariadne and the bacchant, we are invited to recall the extremes of passion and violence of which these figures are capable once awake. Furthermore, this picture of a raging Cynthia would seem to tie in with the torment and anguish Propertius claims to suffer in Poem 1.

As we have seen, many scholars approach Cynthia's speech from this Propertian perspective. To begin with, I want to pursue a reading that resists Propertius for a moment, and to see what happens if we side with Cynthia. We will begin by taking what she says at face value, before exploring the literary texture of her speech in more detail.

compositos levibus radiis patefecit ocellos. sic ait in molli fixa toro cubitum:

'tandem te nostro referens iniuria lecto alterius clausis expulit e foribus?

namque ubi longa meae consumpsti tempora noctis, languidus exactis, ei mihi, sideribus?

\footnotetext{
${ }^{74}$ E. Greene, 'Elegiac Woman: Fantasy, Materia and Male Desire in Propertius 1.3 and 1.11' AJPh 116 (1995) 303-18 (309).

75 Zetzel, 'Baldness' (n. 9, above) 86.

${ }^{76}$ Curran, 'Vision' (n. 3, above) 205.

77 J. F. Miller, Apollo, Augustus, and the Poets (Cambridge 2009) 199.

${ }^{78}$ Dunn, 'Lover' (n. 9, above) 248: though Dunn does acknowledge that the Bacchic fury soon subsides and that 'the fierce Maenad becomes instead a Penelope waiting for Odysseus or an Ariadne abandoned by Theseus'.

${ }^{79}$ As also noted by Kaufhold, 'Propertius’ (n. 9, above), who sees in Cynthia's speech the language of the elegiac lover, and from this, ‘a portrait of a loving mistress’ (97). Michalopoulos, 'Speech’ (n. 9, above) takes a slightly different approach, seeing Cynthia as 'describing herself in accordance with the poet's dictates and desirers'. See below for Cynthia as the elegiac lover.

${ }^{80}$ Cf. 1.3.43 leuiter ... querebar.
} 
o utinam talis perducas, improbe, noctes, me miseram qualis semper habere iubes!

nam modo purpureo fallebam stamine somnum, rursus et Orpheae carmine, fessa, lyrae;

interdum leviter mecum deserta querebar externo longas saepe in amore moras:

dum me iucundis lapsam Sopor impulit alis. $\quad 45$ illa fuit lacrimis ultima cura meis.'

[The moon] opened with its gentle beams Cynthia's fast-closed eyes. Then, with elbow propped on the soft couch, she cried: 'Has another's scorn then at last brought you to my bed, expelling you from doors closed in your face? For where have you spent the long hours of the night which was due me, you who come, ah me, exhausted, when the stars are driven from the sky? Oh, may you spend nights like these, you villain, such as you are always compelling poor me to endure! For now I was beguiling sleep by spinning crimson thread, and now in my weariness by music of Oprheus' lyre; and sometimes, all forlorn, I softly complained to myself of the long time spent by you in another's embrace: till Sleep with soothing wings overcame my exhausted body. That was my weeping's last concern'

Propertius 1.3.33-46

Propertius does not tell us much about what he was up to before the poem began: all we know is that he has been out for most of the night, and he has been drinking. Cynthia, however, suggests that Propertius's night out has had an erotic dimension. She wonders at first whether he has spent his time attempting to gain access to another woman (1l. 35-6); then in the next couplet she suggests that he has been successful, with the post-coital connotations of languidus here coming to the fore; we also learn that this was a night pledged to her (meae ... noctis); finally we learn that not only is this kind of behaviour on the part of Propertius a regular event (semper), but also that far from the over-powering and commanding domina we take her to be, Cynthia is in fact the unhappy half of this relationship (me miseram), and the one who receives rather than gives the orders (me ... habere iubes). In the second half of her speech, the focus turns from Propertius to Cynthia herself. Rather than some grasping sexual mercenary, Cynthia is the faithful wife, spending her time spinning or weaving like those paradigms of virtue Lucretia or Penelope, or playing the lyre, lamenting the way she has been abandoned, until Sleep brings an end to her sadness.

This does not appear to be the traditional picture of Cynthia, or indeed of Propertius: in 1.1 we are introduced to a Propertius who is wretched and emasculated, enduring nights of torment in his love-sick state; in 1.4, in which Propertius rebukes Bassus for his praise of other women, he refers to the servitium (1.4.4) and the furor (1.4.11) of his relationship, and once again Cynthia is characterised as wild and ferocious (1.4.17 insana puella, 1.4.21 irata, cf. also 1.4.23-4); in 1.5, as Gallus attempts to move in on Cynthia, Propertius suggests that life with her corresponds to 'the ultimate in woe' (1.5.4 ultima mala), involving harsh service (1.5.19 graue seruitium), because she is ferocious (1.5.12 ferox) and wild in her rage (1.5.8 molliter 
irasci non sciet illa tibi). Here in 1.3, however, Cynthia's rage does not seem particularly ferocious (compare for example her rage at 4.8.55-80), and Propertius does not seem particularly attentive to the woman a night with whom he later claims might turn a man into a god (2.15.40). Furthermore, in terms of gender, the situation as described by Cynthia seems to contradict the prevailing sense we get from Latin love elegy that the traditional norms of power and gender have been inverted: it is often the case that the female beloved adopts the masculine position of power and control, and the male lover adopts the female position of obedience and passivity. Here, however, it would appear — if we believe what Cynthia says - that the traditional norms have been restored, since she stays faithfully at home while Propertius has been out and about and possibly up to no good.

For some scholars, the solution to this problem is not to take Cynthia at face value at all. Lyne argues that Cynthia's reproaches are unjustified, and are an 'example of her over-hasty, suspicious, irrational [...] nature' (62). ${ }^{81}$ Phrases such as meae noctis are an expression of 'a domineering wife of terrible reality', while words such as semper and iubes are 'contemptuously careless exaggerations', and me miseram introduces 'whining reproach full of self-pity' (76). Indeed, by the time Cynthia finishes 'it is all we can do not to think of her as a wronged innocent' (78): the implication is, of course, that we must struggle not to think of her in this way. The problem is that Propertius (or at least, the 'I' of these poems) and Cynthia seem to be offering different and indeed opposing perspectives on their relationship. Whether or not we ultimately side with Propertius or Cynthia, the important point here is that Cynthia's speech opens up a potential gap in Propertius's credibility, and introduces the Catullan question of perspective and trust: how reliable is our narrator? Can we really believe what he says?

\section{Cynthia as Propertius}

One might be tempted to argue that Cynthia's speech simply suggests a view of the relationship in which normal gender roles are restored, but things are a little bit more complicated than that. The complication arises from the consideration that the 'female' role in love elegy is usually played by the male lover, and that raises the question: is Cynthia now playing the female role, or the role of the effeminised male? I would argue that Cynthia's speech complicates her gender status by revealing a textual relationship with a number of men ranging from Propertius to Hellenistic epigrammatists to Homer.

Let us begin with Cynthia's relationship with Propertius. In her speech Cynthia throws back at Propertius many of the words and images he uses in the first part of the poem, almost as if she has been reading the text: ${ }^{82}$ to Propertius, Cynthia seemed like Ariadne lying 'languid on the deserted shores' (1. 2 languida desertis Cnosia litoribus); Cynthia keeps the idea of desertion, applying it directly to herself (l. 43 deserta querebar), while transferring the languor to Propertius (1. 38 languidus); to Propertius, Cynthia seemed like a wearied Thracian Bacchant (l. 5 Edonis fessa).

\footnotetext{
${ }^{81}$ Lyne, 'Propertius' (n. 4, above).

${ }^{82}$ For different reading of this passage, see Lyne, 'Propertius’ (n. 4, above) 75-78; Kaufhold, 'Propertius' (n. 9, above).
} 
Again, with Orpheae carmine fessa lyrae (1. 42) Cynthia appropriates the weariness, ${ }^{83}$ but she identifies herself not with a dangerous Thracian Bacchant, but — through the detail of the 'Orphean lyre' — with the Bacchants' traditional victim, Orpheus. ${ }^{84}$ Amor and Bacchus may have been giving orders to Propertius (ll. 13f.), but for Cynthia it is the rather less abstract figure of Propertius who gives the orders (1. 40 semper habere iubes). The gods' suggestion that Propertius 'gently make trial' of Cynthia (l. 15 leuiter ... temptare) finds a pointedly more dignified echo in Cynthia 'gently lamenting' (l. 43 leuiter ... querebar). Furthermore, the image with which Cynthia closes the poem, of her succumbing to the wings of Sleep, evokes the series of images with which the poem opened, not just in general terms but also in pictorial detail. $^{85}$

However, her relationship with Propertius's poetry extends beyond the confines of 1.3. Other scholars have noted that when Cynthia says me miseram in line 40 , or ei mihi in line 38, or lapsam in line 45, she is echoing key phrases from the programmatic opening poem (1.1.1 Cynthia prima suis miserum me cepit ocellis; 1.1.7 ei mihi, iam toto furor hic non deficit anno; 1.1 .25 aut vos, qui sero lapsum revocatis, amici).$^{86}$ Furthermore, with leuiter ... querebar Cynthia seems to co-opt two concepts central to elegiac self-definition. ${ }^{87}$

As scholars such as Kaufhold have well documented, ${ }^{88}$ there is a sense then in which Cynthia sounds very much like an elegiac poet, in particular, like Propertius. As Cynthia laments the infidelities of her lover, she claims (or re-claims) not only the 'feminine' role of the elegist, but also his vocabulary. Furthermore, we shall see in a moment how she also lays claim to the technique of elegiac composition more generally.

\section{Propertius as Cynthia}

Before we look further at the ways in which Cynthia has become Propertius, we should note that there is also a sense in which Propertius has become Cynthia. The most straightforward sense in which this is the case is in the role-reversal that Cynthia's speech suggests: according to her, it is Propertius who is the unfaithful beloved, the one who makes the faithful and tormented lover's life a misery. Again, to some extent Propertius is reverting to the 'male' role, but (as we have seen) in love elegy the male role traditionally belongs to the female.

\footnotetext{
${ }^{83}$ It should be noted that the adjective fessus occurs nowhere else in the first two books of Propertius.

${ }^{84}$ At Met. 11.69, Ovid specifies that the Bacchants who dismembered Orpheus were Edonians.

${ }^{85}$ On similarities between the style and tone of Cynthia's speech and the opening of the poem, see Curran, 'Vision' (n. 3, above) 205-06. On the evocation of the opening images, see Wlosok, 'CynthiaElegie’ (n. 9, above) 337; Harmon, 'Myth’ (n. 9, above) 164. For artistic representations of sleepers and Hypnos, see McNally, 'Ariadne’ (n. 2, above) and further references in note 107.

${ }^{86}$ On this see especially Kaufhold, 'Propertius' (n. 9, above). Cynthia also re-uses some Propertian language from 1.1 in a similar way to that of 1.3: when she addresses Propertius as improbe in 1.3.39 she is putting a different spin on the word that Propertius applied to himself at 1.1.5f. donec me docuit castas odisse puellas / improbus. Cynthia suggests that while Propertius might have learnt to dislike chaste women, he perhaps enjoys the company of less fastidious ladies.

${ }^{87}$ See Kaufhold, 'Propertius' (n. 9, above), 95.

${ }^{88}$ Kaufhold, 'Propertius' (n. 9, above).
} 
However, the text also suggests links between Propertius and Cynthia on a more subtle level. The sleeping figures of Ariadne and the Bacchant at the opening of 1.3 evoke a visual as well as literary memory: both figures were frequently depicted in art, ${ }^{89}$ and the invitation to recollect these representations and to reflect on this idea of 'viewing' Cynthia as if gazing at a series of paintings is an important part of the poem. I would suggest that when a reader recalls these two familiar scenes of sleeping, they might well be tempted to recall another commonly depicted sleeping figure, often represented in a similar pose, namely Endymion. ${ }^{90}$ Endymion was the beloved of Selene, the moon, who in art is often depicted coming down from the heavens, gazing at Endymion as he sleeps. As the internal viewer, Selene forms the counterpart to Theseus and Bacchus in the case of Ariadne, or the satyr in the case of the sleeping Bacchant. ${ }^{91}$ However, such recollections may stay at the back of the reader's mind for the moment, as after all, in this case the sleeper is a male, and the viewer a female, and the genders are all wrong for Cynthia and Propertius.

However, a further push to recall Endymion comes a little later when the Moon is introduced into the narrative, and personified in the process:

\section{donec diversas praecurrens luna fenestras, luna moraturis sedula luminibus, compositos levibus radiis patefecit ocellos.}

At length the moon hurrying by the parted shutters, the officious moon with light that would fain have stayed, opened with its gentle beams Cynthia's fast-closed eyes.

Playing upon the double sense of lumina as both 'beam of light' and 'eyes', Propertius presents us with the Moon in a familiar role as a viewer. Scholars have noted the echo of an epigram of Philodemus on a similar subject: ${ }^{92}$

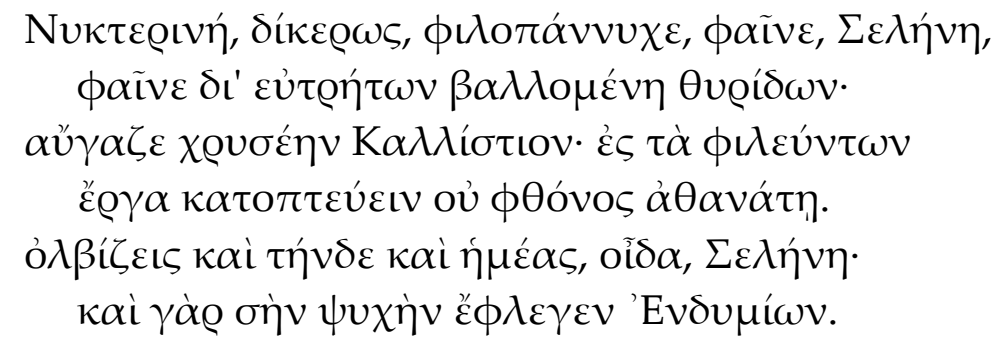

\footnotetext{
${ }^{89}$ See note 2.

${ }^{90}$ Though there is one other figure who is often represented asleep in this pose, to whom we shall turn shortly. For the sleeping figure of Endymion, see McNally, 'Ariadne' (n. 2, above); LIMC vol. 2, s.v. Endymion, esp. nos. 22, 24, 46, 50, 54, 93, 94; Stafford, 'Sleep’ (n. 2, above); Hodske, Bildthemen (n. 2, above) 210-12.

${ }^{91}$ When Andromeda, who as far as we can tell was not depicted sleeping in art, is depicted between the frequently depicted figures of Ariadne and the Bacchant, her unexpected presence here may provide further impetus to recall more familiar sleeping figures.

${ }^{92}$ On the relationship between Propertius 1.3 and this epigram, see Booth, 'Moonshine' (n. 9, above).
} 
Shine, moon of the night, two-horned Moon, who loves to look on revels, shine through the lattice and let your light fall on golden Callistion. It is no offence for an immortal to pry into the secrets of lovers. You bless her and me, I know, O Moon; for did not Endymion set your soul on fire? ${ }^{93}$

Philodemus, AP 5.123

The Philodemus epigram explicitly mentions Endymion in this context, and it is particularly appropriate here: the moon has a history of gazing on sleeping beauties, and now both Propertius and the moon are gazing on the sleeping Cynthia. In one sense the moon is a rival to Propertius, but in another (particularly when we think of Endymion together with Ariadne and the Bacchant) the moon is an analogue for Propertius. ${ }^{94}$ This starts to become particularly relevant for our purposes when recall that the moon was often indentified with Diana, the sister of Apollo. ${ }^{95}$ Now Apollo can sometimes be referred to as Cynthius, and his sister, Diana, can sometimes be referred to as Cynthia. ${ }^{96}$

So there are various ways in which Propertius has become Cynthia, and as we shall see, there are still further ways in which Cynthia has become Propertius. If we return now to her speech, we will see how she adopts not just Propertian language, but Propertian technique in the complex literary textures she weaves. ${ }^{97}$ But Cynthia will also be aligning herself with many other characters and character-traits too, encouraging us to see her in various different — and indeed contrasting — lights simultaneously.

The complex literary texture of the speech first begins to manifest itself at lines 39-40: o utinam talis perducas, improbe, noctes, / me miseram qualis semper habere iubes. Here Cynthia simultaneously evokes a variety of earlier texts and a variety of speakers: the wish that Propertius suffer such nights as she is forced to endure is the first of many echoes of Hellenistic epigram in this passage, in this case echoing an epigram attributed to Callimachus: ${ }^{98}$

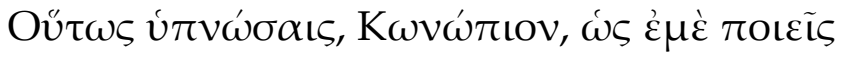

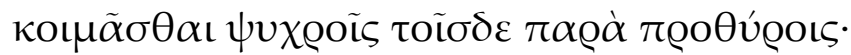

\footnotetext{
93 Translation that of W. R. Paton, The Greek Anthology. Volume I (Cambridge MA 1916) with slight modifications.

${ }^{94}$ For a slightly different take on Propertius's relationship to the Moon and the gender-instability that results, see Valladares, 'Lover' (n. 9, above) 228-38.

${ }^{95}$ Cf. e.g. Cat. 35.16; Hor. Carm. Saec. 1-2, 35-6.

${ }^{96}$ Cf. e.g. Hor. Carm. 3.28.12; Ov. Met. 2.465, Fast. 2.91. For more on the play between Cynthia and the moon in Propertius, see E. O’Neil, 'Cynthia and the Moon', CPh 53 (1958) 1-8.

${ }^{97}$ That is to say, the character Cynthia (created by the poet) speaks like the character 'Propertius' (created by the poet). For a discussion of how the allusive texture of her speech complicates our response to the idea of the 'reality' of Cynthia's response (in mimetic terms), see Breed, 'Portrait' (n. 9, above).

98 The complaint of the lover who has spent a lonely night without his beloved is a common theme in epigram: on the relationship of Cynthia's speech to this theme, and the inversion of gender that it entails, see G. Giangrande, 'Los tópicos helenísticos en la elegía latina’, Emerita 42 (1974) 1-36.
} 


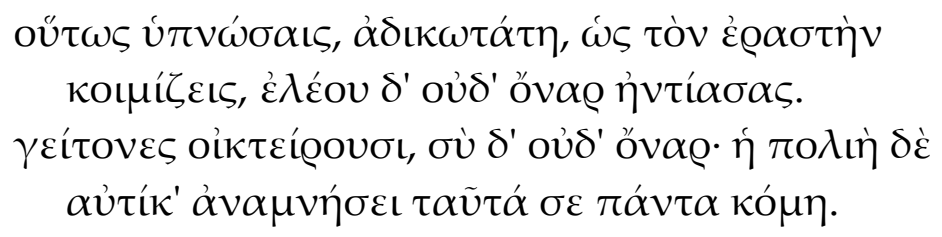

May you so sleep, Conopion, as you make me sleep by these cold portals; may you sleep even so, cruel one, as you send him who loves you to sleep. Not a shadow of pity touched you. The neighbours take pity on me, but you not a shadow. One day shall the grey hairs come to remind you of all this.

Callimachus Ep. $63=$ AP 5.23

Here, as she will continue to do, Cynthia speaks like a Hellenistic male poet, albeit a Hellenistic male poet who has been effeminized by love - simultaneously male and female. With me miseram she reminds us of both Propertius (see above) but also Ariadne, who refers to herself in similar terms in two passages to which Cynthia will allude again in her speech (64.56 desertam in sola miseram se cernat harena; 64.70f. misera, ... quam ... externauit / ... Erycina serens in pectore curas). Just as Propertius did at the opening, Cynthia will also allude to key moments of Catullus 64, with her 'curse' on Propertius (talis noctes ... qualis... ) echoing in structure Ariadne's curse on Theseus, which closes her speech at 64.200-1 sed quali solam Theseus me mente reliquit, tali mente, deae, funestet seque suosque.

In the next couplet (ll. 41-2 nam modo purpureo fallebam stamine somnum, / rursus et Orpheae carmine, fessa, lyrae), this dynamic of the simultaneous representation of conflicting images continues, as Cynthia imagines herself weaving and playing the lyre. The picture of Cynthia working at her wool while her man is absent resonates on a number of levels: she evokes the image of Lucretia, the paradigm of Roman womanly virtue and a symbol of fidelity that holds a particular fascination for the elegiac poets; ${ }^{99}$ but she also evokes Penelope, whose weaving was linked to her fidelity in a different and slightly less straightforwardly Roman way: ${ }^{100}$ her trickery is recalled by the phrase fallebam ... somnum. However, the same phrase also serves to recall — while the same time differentiating Cynthia from - Ariadne at the opening of her ekphrasis in Catullus 64, when she awakes from 'deceitful sleep' (64.56 utpote fallaci quae tum primum excita somno): Cynthia takes a more active role here, attempting to deceive sleep rather than being deceived by it. The detail of the purple thread is also doing a lot of work: first, it evokes another key image from Catullus 64, the purple thread that runs throughout the poem, surfacing in the bedspread of Peleus and Thetis (49), in the bedspread that Ariadne imagines laying out for Theseus (162f.), of the sunlight in the simile (275), and finally in the clothes of the Fates (308). ${ }^{101}$ Second the exotic colour purple complicates the picture of Cynthia

\footnotetext{
${ }^{99}$ See M. Robinson , A Commentary on Ovid's Fasti, Book 2 (Oxford 2010) on Fasti 2.741-60.

${ }^{100}$ In a bid to keep the suitors at bay, Penelope famously told them that she could not marry until she had finished weaving a shroud for Laertes. She wove the shroud during the day, and unpicked it at night, before a maid finally revealed the trick to the suitors (Od. 2.85-110). However, such duplicity is not an uncomplicated virtue for traditional Roman morality.

${ }^{101}$ On this see Sklenář, 'Fabrics’ (n. 26, above) and Elsner, ‘Ariadne’ (n. 9, above) 23.
} 
as a chaste Lucretia: as has been noted, the expense and glamour of purple suits the character of a courtesan better than it does a Lucretia; ${ }^{102}$ furthermore, in the Homeric world, it is the adulterous Helen who is found weaving with purple wool. ${ }^{103}$ Yet the world of painting may pull us again in a different direction, for we find the chaste Penelope depicted holding a ball of purple wool. ${ }^{104}$ The lyre has similarly complex associations: as we have seen, on one level this negates the latent violence suggested in the image of the Bacchant, with Cynthia portraying herself as victim not as the aggressor; it also identifies her again as the poet, reinforcing the metapoetic sense of leuiter querebar in the following couplet; yet it might also mark her out as inappropriately skilled on an instrument at which a Roman matrona should not be too proficient. ${ }^{105}$

In the couplet that follows (ll. 43-4 interdum leviter mecum deserta querebar / externo longas saepe in amore moras), we saw earlier how Cynthia co-opts the vocabulary of elegiac composition with leuiter querebar. Once again she also recalls and differentiates herself from Ariadne: she is deserta like Ariadne was at the beginning of the poem, and in Catullus 64; and with the adjective externo she recalls the repeated use of the verb exsterno to describe Ariadne (64.71f. misera, assiduis quam luctibus exsternavit / ... Erycina; 64.165 exsternata malo). ${ }^{106}$ With her 'gentle laments' (leuiter ... querebar) she picks up the 'final laments' of Ariadne (64.130 extremis ... querellis): however, the phrase occurs towards the end of Cynthia's speech, where it captures both the brevity and elegiac nature of her words; in Catullus, however, the phrase introduces Ariadne's speech, where for a Propertian reader it may appear to be a case of misdirection: for Ariadne's words are not elegiac querellae as we have come to know them, but rather they form a lament whose length and passion smacks more of tragedy and epic.

In the final couplet (ll. 45-6 dum me iucundis lapsam Sopor impulit alis. / illa fuit lacrimis ultima cura meis), Cynthia finishes her speech asleep, as it were, in the arms (or perhaps wings) of Sleep, recalling the pose in which Ariadne and Endymion are often found. ${ }^{107}$ She recalls both Propertius's Ariadne as she sleeps at the opening of this poem, but also the Ariadne of Catullus, at the close of the ekphrasis, where we leave her 'turning over many cares in her heart' (64.250 multiplices animo uoluebat saucia curas). When Cynthia recalls how 'Sleep drove her with his wings' the image evokes the fierce loyalty of Iris, Juno's messenger, who as Callimachus tells us in the his Hymn to Delos never forgets her seat, 'not even when sleeps lays upon her his

\footnotetext{
102 Cf. Harmon, 'Myth’ (n. 9, above) 162-63; Harrison, 'Drink' (n. 5, above); Michalopoulos, 'Speech' (n. 9, above) 8-9.

${ }^{103}$ Cf. Hom. Il. 3.125f.; and see Michalopoulos, ‘Speech’ (n. 9, above) 8-9.

${ }^{104}$ For a colour image, cf. e.g. http://bit.ly/MRaLLf. For a slightly enhanced version , see http://bit.ly/MsUeBm. Michalopoulos, 'Speech’ (n. 9, above) 9 sees this ‘contradictory self-description both as a paradigm of ... integrity and ... of wantonness' as a deliberate ploy by Cynthia to make her more desirable to Propertius, appealing to the fantasy figure of the woman who is both virgin and whore.

${ }^{105}$ Cf. Harmon, ‘Myth’ (n. 9, above) 162; Harrison, ‘Drink’ (n. 5, above); Tatham, ‘Ariadne’ (n. 5, above) 52-3 who compares Meleager AP 5.175; Michalopoulos, ‘Speech’ (n. 9, above) 8, n. 40.

${ }^{106}$ We have seen intertextuality with both these lines before: see above. See also Curran, 'Vision' (n. 3, above) 206, n. 21.

${ }^{107}$ Cf. McNally, 'Ariadne’ (n. 2, above). For Ariadne and Hypnos, cf. e.g. LIMC vol 3, addenda, s.v., nos. 52, 53, 54; for Endymion and Hypnos, cf. e.g. LIMC vol. 3, s.v., nos. 46, 50, 54, 93, 94.
} 


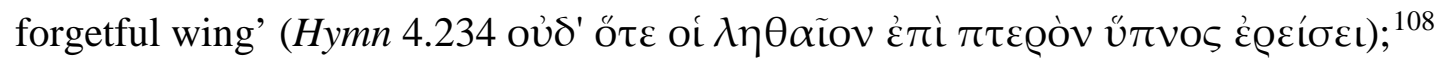
but she also recalls the loyal and long-suffering Penelope, whose weeping for

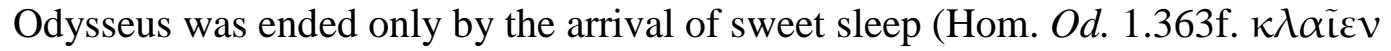

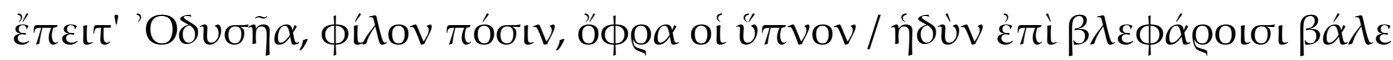
$\gamma \lambda \alpha v \kappa \tilde{\omega} \pi\left\llcorner\varsigma^{\prime} \mathrm{A} \theta \dot{\eta} v \eta\right) .{ }^{109}$ The cura and lacrimae with which Cynthia closes the poem are appropriately elegiac concerns, but with cura we find another example of the combination of opposites we have seen throughout this speech: cura can mean 'concern' or 'cure', and both meanings are active simultaneously here. With ultima cura in the sense of 'final concern' she echoes the curas with which Ariadne's ekphrasis comes to a close, and the extremae querellae with which her lament was introduced (see above); yet in the sense of 'final cure', the phrase aligns her once again with Penelope, for whom sleep brought an end to her weeping.

So Cynthia closes the poem as Ariadne, as Penelope, as Propertius, as a shrewish nag, as a devoted wife, as woman and as a man - and perhaps one last famous sleeping figure. ${ }^{110}$ What are we to make of this?

The lesson we learn from Catullus 64 is that we cannot always trust our narrator, especially when the narrator constantly draws attention to the unreliable - or perhaps it would be better to say 'artificial' - nature of his narrative. In presenting us with an array of competing or indeed opposing perspectives Catullus may be drawing attention to the problems of mimesis, but he is simultaneously drawing attention to the poet's control of the poem and the reader, a control which is underlined by the artificiality of the world he has created, and by the uncertainty it creates in the reader.

So when in 1.3 we see Cynthia as both devoted wife and as lush courtesan, or as lover and beloved, we are not seeing 'harsh reality'. We are seeing a figure who is clearly marked as a poetic creation, a point underlined by her association with figures from the world of art. ${ }^{111}$ The idea that Cynthia is herself a work of art is not a new one, ${ }^{112}$ but I would argue that when Cynthia becomes Propertius, using his language, but also his mannered poetic technique, and when Propertius becomes Cynthia, then we must question the extent to which Propertius too is a poetic creation - a persona created by the poet. The suggestion that elegy is an artificial genre is also hardly new, but I would suggest that this poem points more explicitly in that direction than has previously been thought. We can situate Propertius 1.3 in a poetic continuum that ranges from Catullus 16 to Amores 1.1, as a poem that lifts the curtain on the artificial nature of the elegiac persona, and warns us that all might not be as it seems. This will not be the only time that this happens in Propertius: indeed right at the start of the

\footnotetext{
108 The Callimachean line appears to be the first time in extant literature that Sleep appears with wings, though he is depicted with wings from an early stage in Greek vase-painting.

109 'Then she wept for Odysseus, her dear husband, until gleaming-eyed Athena cast sweet sleep upon her eyelids'

${ }^{110}$ In this she resembles another famous sleeping figure, namely Hermaphroditus: for representations in art, see Stafford, 'Sleep' (n. 2, above).

111 There is a sense that when, just before she wakes, Propertius refers to Cynthia's 'eyes composed in sleep' (compositos ocellos), he is drawing attention to the fact these eyes (the ocelli which are the very first aspect of Cynthia to which we are introduced, in the very first line of Propertius's oeuvre), are 'composed' in a literal sense.

112 Cf. Breed, 'Portrait' (n. 9, above) on this poem, and M. Wyke, The Roman Mistress: Ancient and Modern Representations (Oxford 2002) on Cynthia and the concept of the 'elegiac woman' more generally.
} 
Propertian corpus, poem 1.1 complicates the emotional intensity of its opening lines by their allusive play with Greek epigram; and of course the two Cynthia poems of Book 4, 4.7 and 4.8, will explode Propertius's myth in spectacular style. ${ }^{113}$

Through its recognition and reproduction of key features of Catullus 64, Propertius 1.3 acknowledges the important role played by Catullus in the elegiac tradition; and, like Catullus, through the destabilising effect of the clash of opposing perspectives, he draws attention to the fictionality of his world, but also therefore, to the fact that this is his creation, and that ultimately he is master over it. For all the gender uncertainty of elegiac lover, Propertius reminds us that he is, after all, the man.

\footnotetext{
${ }^{113}$ I would suggest that the series of poems 1.1, 1.2, 1.3 and 1.4 present different aspects of Propertius's relationship with Cynthia in a way that is potentially more problematic than is often thought. Lyne, 'Introductory Poems in Propertius: 1.1 and 2.12', PCPS 44 (1998) 158-81 notes the problem and offers a solution (that each poem has a different addressee), though I am not sure how 1.15 (in which Propertius seems to have no problem uttering his angry words) would fit with this reading.
} 